\title{
Brian O’Nolan’s “Tales from Corkadorky” and Sgéalta Mhuintir Luinigh
}

\author{
Tobias Harris \\ University of London, United Kingdom
}

Copyright (c) 2021 by Tobias Harris. This text may be archived and redistributed both in electronic form and in hard copy, provided that the author and journal are properly cited and no fee is charged for access.

\begin{abstract}
This essay addresses a relatively untouched topic in the field of Brian O'Nolan / Flann O’Brien studies: the Irish-language "Tales from Corkadorky” vignettes published during 1941-42 in the "Cruiskeen Lawn” column O’Nolan wrote as Myles na gCopaleen for the Irish Times. This essay builds on the brief existing critical remarks about this series of columns by exploring, in unprecedented detail, Breandán Ó Conaire’s suggestion that the "Tales from Corkadorky” are modelled on the Sgéalta Mhuintir Luinigh (Munterloney Folktales) collected by Professor Éamonn Ó Tuathail and published in 1933. After summarising existing criticism, the essay presents the wider context of folklore collection for O'Nolan's work in Irish, the background linking him to Ó Tuathail's Sgéalta Mhuintir Luinigh, and proceeds to conduct a comparative reading of O'Nolan's use of dialect features and themes from this source material in the "Tales from Corkadorky". Facilitated by its analysis of the first tale to appear, the essay traces the origin and development of the tale format as it interacts with other recurring elements in "Cruiskeen Lawn".
\end{abstract}

Key Words. Brian O’Nolan, Flann O’Brien, Éamonn Ó Tuathail, Folklore, Newspapers.

Resumen. Este artículo aborda un tema relativamente poco estudiado en el campo de los estudios de Brian O'Nolan / Flann O'Brien: las viñetas en irlandés “Tales from Corkadorky" publicadas durante 1941-1942 en la columna “Cruiskeen Lawn”, que O’Nolan escribió como Myles na gCopaleen para el Irish Times. Este ensayo se basa en el análisis de los breves comentarios críticos existentes sobre esta serie de columnas, al explorar, con detalle, la sugerencia de Breandán Ó Conaire de que los “Cuentos de Corkadorky” se inspiran en la Sgéalta Mhuintir Luinigh (Cuentos populares de Munterloney) recopilados por el catedrático Éamonn Ó Tuathail y publicados en 1933. Después de resumir la crítica existente, el artículo presenta el contexto más amplio de la colección de folclore para el trabajo de O’Nolan en irlandés, cuyos antecedentes lo vinculan con Sgéalta Mhuintir Luinigh de Ó Tuathail, y se procede a realizar una lectura comparativa del uso de O’Nolan de características del dialecto y temas de otras fuentes en los "Cuentos de Corkadorky”. Gracias al análisis del primer cuento 
que aparece, el artículo rastrea el origen y desarrollo del formato de cuento en su interacción con otros elementos recurrentes en “Cruiskeen Lawn”.

Palabras clave. Brian O’Nolan, Flann O’Brien, Éamonn Ó Tuathail, folclore, periódicos.

\section{Introduction}

Among Brian ONolan's three early novels, At Swim-Two-Birds (1939), The Third Policeman (written 1939-40, published 1967) and An Béal Bocht (written 1940, published December 1941 and translated as the The Poor Mouth in 1973), it is this last, a comic response to swathes of the Irish-language literary tradition but most obviously a pastiche of Tomás Ó Criomhthain's autobiographical work, An tOileánach (The Islander, 1929), that seems most closely associated with the "Cruiskeen Lawn” column which O'Nolan had started writing under the pen name Myles na gCopaleen ("Myles of the Little Horses") for the Irish Times as an Irishlanguage feature in October 1940. An Béal Bocht is brought to readers by an "editor” also named Myles na gCopaleen and its fictional zone of "Corca Dorcha” re-emerges in the pages of the Irish Times in a series of vignettes published during 1941-42 entitled "Tales from Corkadorky". ${ }^{1}$ Like the novel's Bónapart Ó Cúnasa, the characters in these tales are rainedupon, hungry and subject to the depredations of Gaelic literary clichés. This essay builds on the short existing critical remarks about this series of columns by exploring, in unprecedented detail, Breandán Ó Conaire's suggestion that the "Tales from Corkadorky" are modelled on the Sgéalta Mhuintir Luinigh (Munterloney Folktales) collected by Professor Éamonn Ó Tuathail and published in 1933. After summarising existing criticism, the essay presents the wider context of folklore collection for O’Nolan's work in Irish, the background linking him to Ó Tuathail's Sgéalta Mhuintir Luinigh, and proceeds to conduct a comparative reading of O'Nolan's use of dialect features and themes from this source material in "The Tales from Corkadorky". Facilitated by its analysis of the first instance of one of the tales, the essay traces the origin and development of the tale format as it interacts with other recurring elements in “Cruiskeen Lawn”. In conclusion, the essay draws on Vito Carrassi's reading of O'Nolan in the light of folklore theory to argue that, by incorporating language and themes from Ó Tuathail's book into its developing set of varied sketches, the column injects new life and new interpretive possibilities into the stories recorded by Ó Tuathail in Munterloney.

\section{Ó Conaire on the “Tales from Corkadorky”}

In a brief note which forms part of his catalogue of the numerous subgenres which appear in Cruiskeen Lawn, Ó Conaire writes that the examples of "scigscéalta" ("folktales") in Cruiskeen Lawn which are mostly given the title of "Tales from Corkadorky" are "bunaithe ar shaothar Éamoinn Uí Thuathail, Sgéalta Mhuintir Luinigh" ('modelled on a work of Éamoinn Uí Thuathail, Munterloney Folktales'; Ó Conaire, Myles 64). Ó Conaire lists each example of the "scigscéalta” ("folktales") he says Sgéalta Mhuintir Luinigh inspired, including all those with the title of "Tales from Corkadorky" in the column but also several others (Ó Conaire, Myles, 64, 263). Later, in a book review, Ó Conaire describes the tales as a "series of very funny vignettes" and records in a footnote that some of them "were later reprinted by his brother Ciarán Ó Nualláin in Inniu, 19, 26 Aibreán 1968” (197). This essay will explore Ó Conaire's suggestion in more detail. Its starting point is the table below which expands on Ó Conaire's list by adding the following information to each column he includes: the other subtitled sections that appear in the same column; notation about their use of Gaelic or Roman script; and some notes about the characters who appear in the main "tale" and its surrounding 
material. Although by no means exhaustive, the table provides a map of the material as a reference point for the rest of this essay's discussion.

Table 1

Notes on sections and characters in Columns noted by Ó Conaire as including "scigscéalta”:

\begin{tabular}{|c|c|c|}
\hline Date & $\begin{array}{l}\text { - Sections (main script used } \\
\text { /secondary script used) } \\
\text { [Notes on content] }\end{array}$ & Synopsis and further notes \\
\hline 08/02/1941 & 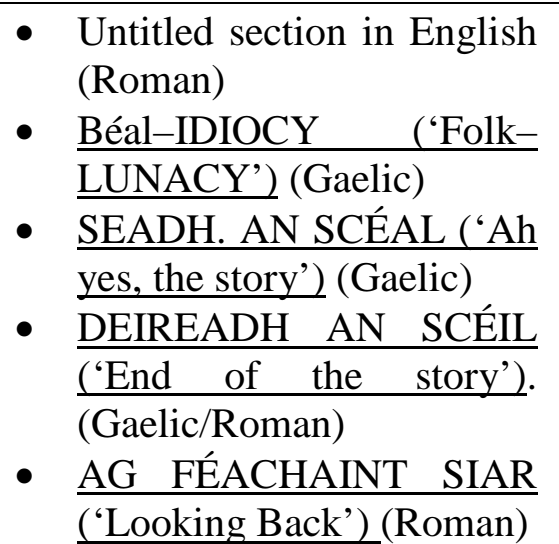 & $\begin{array}{l}\text { Myles introduces the folktale } \\
\text { material as a story he has } \\
\text { collected from an elder in } \\
\text { Connemara, referring to the } \\
\text { "Institúit Béaloideasa" In the } \\
\text { story he relates, the devil traps a } \\
\text { character named Niall Dubh in his } \\
\text { bag by telling him there are } \\
\text { pennies inside when they meet on } \\
\text { the road and "there is never heard } \\
\text { a story about him again". }\end{array}$ \\
\hline 15/02/1941 & 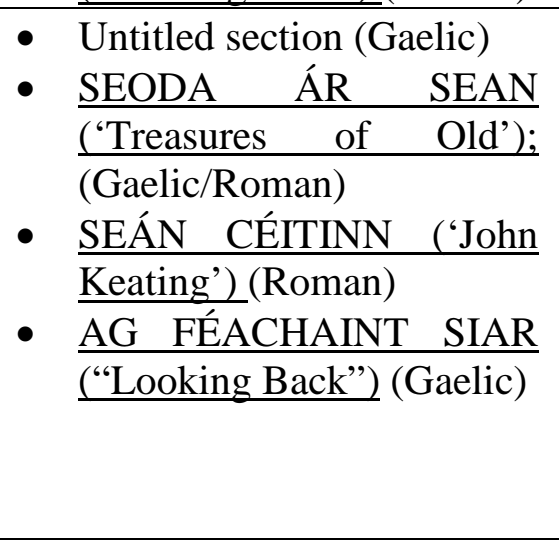 & $\begin{array}{l}\text { Now entitled "Treasures of Old", } \\
\text { perhaps his first idea for naming } \\
\text { the series, Myles tells a story } \\
\text { involving Patsie, Tom, Drummer, } \\
\text { Soogroos and Téig and prints a } \\
\text { picture he says is the director of } \\
\text { the Folklore Institute, clutching a } \\
\text { bag of old language. There is also } \\
\text { an early example of a "Keats and } \\
\text { Chapman" story in English (see } \\
\text { Best of Myles (180-200). }\end{array}$ \\
\hline 18/02/1941 & $\begin{array}{l}\text { - Untitled section with verses } \\
\text { (Gaelic) } \\
\text { - } \frac{\text { TALES }}{\text { CORKADORKY - I I }} \\
\text { - } \frac{\text { AM AGUS AIMSEAR }}{\text { ('Time and the Times') }} \\
\text { (Gaelic) }\end{array}$ & $\begin{array}{l}\text { The folktale section, now entitled } \\
\text { "Tales from Corkadorky", tells a } \\
\text { story about "Teig na Gorta" and } \\
\text { his unwilling marriage to an old } \\
\text { woman. }\end{array}$ \\
\hline 01/03/1941 & \begin{tabular}{ll} 
- & \multicolumn{2}{l}{ Untitled section (Gaelic) } \\
- & TALES \\
CORKADORKY - II \\
- $\frac{\text { AN Boman) }}{\text { ANAILE S'AGAINNE }}$ \\
$\frac{\text { ('Our (Gaelic/Roman) }}{\text { (Gown') }}$
\end{tabular} & $\begin{array}{l}\text { The second tale to be titled as } \\
\text { such introduces [Éamon an } \\
\text { Chnoic], bho is so cold he asks a } \\
\text { "Police Sarjint" for the way to } \\
\text { hell and trades places with the } \\
\text { devil. Referring to a medieval } \\
\text { Irish poem, the "An Baile } \\
\text { S'Againne" section claims that a } \\
\text { reprinted engraving depicts }\end{array}$ \\
\hline
\end{tabular}




\begin{tabular}{|c|c|c|}
\hline & - $\frac{\text { SEAN-CHAINNT }}{\text { Talk') }}$ ('Old & $\begin{array}{l}\text { "Mise", "Pangur Bán”, "Pangur } \\
\text { Dubh" and other Pangurs, until } \\
\text { the joke is interrupted by } \\
\text { "Taidhgín Slánabhaile” or "T.S”. }\end{array}$ \\
\hline 22/03/1941 & 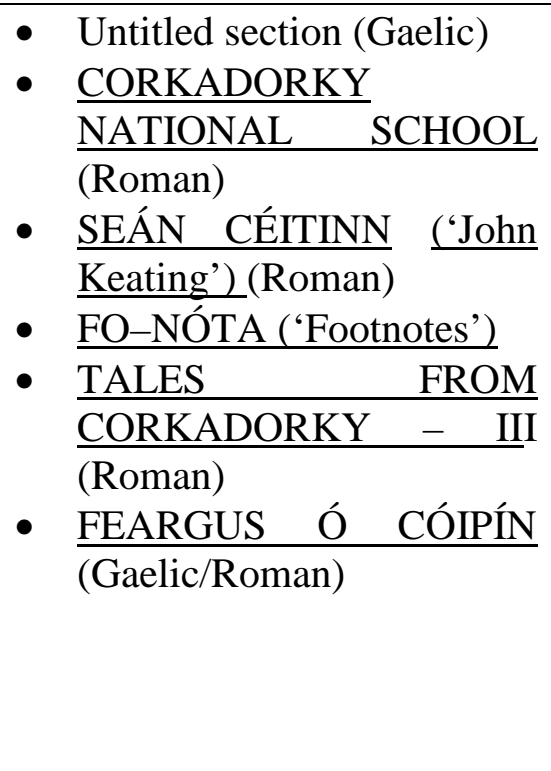 & $\begin{array}{l}\text { This column introduces a new } \\
\text { idea for a sketch that also refers to } \\
\text { themes from An Béal Bocht, the } \\
\text { "Corkadorky National School”, in } \\
\text { which Téig urges a "Colleen } \\
\text { Ogue" ("Young Girl") to attend } \\
\text { school and learn English and the } \\
\text { girl rejects it as not a language but } \\
\text { "glug-glug" for poor people in } \\
\text { Dublin. } \\
\text { There is another Keats and } \\
\text { Chapman sketch told in English. } \\
\text { The tale concerns a character } \\
\text { named "Brian" who lives in a cold } \\
\text { house without a door or glass in } \\
\text { the windows. }\end{array}$ \\
\hline 08/04/1941 & $\begin{array}{ll}\text { - } & \begin{array}{l}\text { Untitled } \\
\text { (Gaelic/Roman) }\end{array} \\
\text { - } & \text { section } \\
\text { TALES } & \text { FROM } \\
\text { CORKADORKY - IV } \\
\text { (Roman) } \\
\frac{\text { HOME HINTS (Gaelic) }}{\text { [with illustrating image] }}\end{array}$ & $\begin{array}{l}\text { The fourth named tale introduces } \\
\text { "Síomus 'ac Réics" ("Jack"), a } \\
\text { likely reference to Sgéalta } \\
\text { Mhuintir Luinigh. }{ }^{\text {c The "Home }} \\
\text { Hints" section, including an } \\
\text { image, offers guidance on how to } \\
\text { tie your boots. }\end{array}$ \\
\hline 05/07/1941 & $\begin{array}{ll}\text { - } & \text { Untitled section (Gaelic) } \\
\text { - } & \text { TALES FROM } \\
\text { CORKADORKY - V V } \\
\text { - } \frac{\text { CÉ HÉ FÉIN? ('Who is }}{\text { that?') (in English) }} \\
\text { - } \frac{\text { SCHOLARLY }}{\text { FOOTNOTE [a Keats \& }} \\
\text { - } \frac{\text { AGUISÍN ('Addendum') }}{\text { (Keats \& Chapman in }} \\
\text { English with image] }\end{array}$ & $\begin{array}{l}\text { The fifth named tale also } \\
\text { mentions "Síomus 'ac Réics", this } \\
\text { time as one of three sons of a great } \\
\text { king of the area. There is another } \\
\text { long journey, another encounter } \\
\text { with the devil and the "senseless } \\
\text { rambling story" proceeds until, as } \\
\text { noted in Taaffe (101-102), } \\
\text { Slánabhaile intervenes to protest: } \\
\text { "why are you putting a story in the } \\
\text { paper that has no sense in it and } \\
\text { which you don't understand } \\
\text { yourself?" (translated in Taaffe } \\
\text { 102). }\end{array}$ \\
\hline 28/08/1941 & 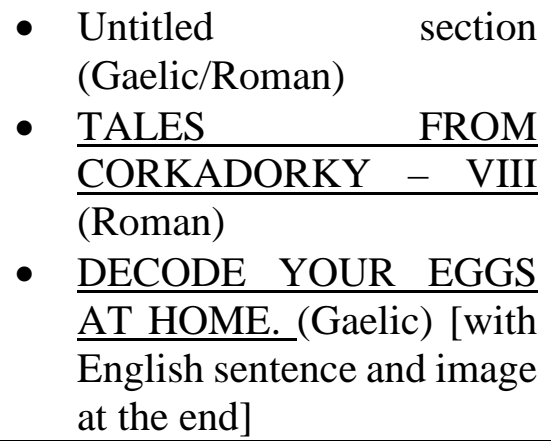 & $\begin{array}{l}\text { The next tale is titled as the } \\
\text { eighth, even though the sixth has } \\
\text { not appeared and the seventh will } \\
\text { appear two days afterwards. It } \\
\text { begins with Slánabhaile, who } \\
\text { interrupts to demand that the } \\
\text { putative subject of the tale, "Brian } \\
\text { "ac Randó", is given a more } \\
\text { suitable name. Like that of the }\end{array}$ \\
\hline
\end{tabular}




\begin{tabular}{|c|c|c|}
\hline & & $\begin{array}{l}\text { author, "Mise", T.S.'s name is } \\
\text { printed in Gaelic script but the } \\
\text { text of the tale is Roman script. }\end{array}$ \\
\hline 30/08/1941 & 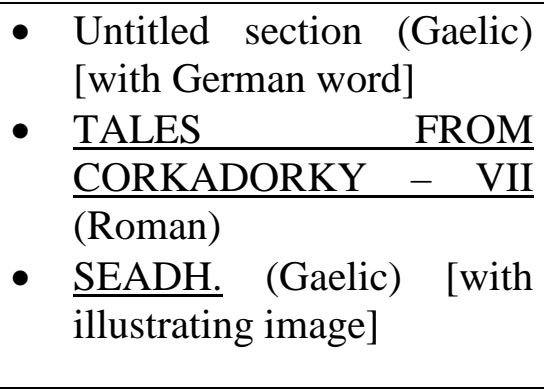 & $\begin{array}{l}\text { "Síomus 'ac Réics" returns in the } \\
\text { seventh tale to feature in a story } \\
\text { involving "Biddy 'ic Ruairí,, a } \\
\text { hunt for a dress in to marry her in, } \\
\text { the inevitable meeting with the } \\
\text { devil and a "polisman" who takes } \\
\text { Síomus to a barracks. He ends up } \\
\text { in jail for two years. }\end{array}$ \\
\hline 03/10/1941 & $\begin{array}{ll}\text { - } & \text { Untitled section (Gaelic) } \\
\text { - } & \frac{\text { TALES FROM }}{\text { CORKADORKY (Roman) }} \\
\text { - } \frac{\underline{\text { SMAOINEAMH }} \text { ('A }}{\text { thought') }} \\
\text { - } \frac{\text { INFAelic) }}{\text { [WAMA in Irish] }} \\
\underline{\text { PLEASE. }}\end{array}$ & $\begin{array}{l}\text { The tale published on } 3 \text { October } \\
1941 \text { does not bear a numeral. } \\
\text { Once again it concerns Síomus } \\
\text { and the devil, and this time his } \\
\text { problem is his extreme hunger. } \\
\text { The column also features, in Irish } \\
\text { and printed in Gaelic script, a } \\
\text { "Thought" about Seán Ó } \\
\text { Faoláin's WAAMA organisation, } \\
\text { a theme that develops into an } \\
\text { English language sequence (see } \\
\text { Best of Myles 15-40). }\end{array}$ \\
\hline 22/01/1942 & $\begin{array}{l}\text { - Untitled section including } \\
\text { - } \frac{\text { COLE (Roman) }}{\text { 'Warlikeness'(Gaelic) }} \\
\text { - } \frac{\text { SEADH. (Gaelic) }}{\text { - }} \frac{\text { AG FÉACHAINT SIAR. }}{\text { (Gaelic) [with illustrating }} \\
\text { image] }\end{array}$ & $\begin{array}{l}\text { The recognisable formula of a tale } \\
\text { reappears on } 22 \text { January 1942, } \\
\text { even though it is no longer titled } \\
\text { as such and now Síomus is } \\
\text { described as hailing from "Corcha } \\
\text { Dorcha" rather than } \\
\text { "Corkadorky", further associating } \\
\text { the material with An Béal Bocht. }\end{array}$ \\
\hline
\end{tabular}

Sources: Irish Times archive and footnote 56 in Ó Conaire, Myles, 263, where he notes “"Tales from Corkadorky' an teidal a chuireadh sé ar fhormhór na scéalta seo” ("The title 'Tales from Corkadorky' is given to most of these stories”).

a An unusual, archaic spelling of "aimsir” (weather, time or season), listed in Léamh: Learn Early Modern Irish, University of Connecticut, Web. 8 Feb. 2021.

$<$ https://xn--lamh-bpa.org/glossary/aimsear/>.

b Printed "Eamon a' Chruic", which is probably a misprint of "Éamon an Chnoic" ("Ned of the Hill"), the title of a traditional Irish song.

" Síomus is the name of the title character in "Síomus Ó Luinín", one of the Sgéalta Mhuintir Luinigh (2279-2409) stories, where Síomus appears many times.

d The fada on Ó is omitted in the printed column, which is probably a misprint.

The table reveals an evolution, over the course of eleven columns published between February 1941 and January 1942, of the distinctive style of the "Tales from Corkadorky" series, even though that title is not actually used until the third tale, dated 18 February 1941. Having set out the material, this essay now addresses critical remarks about the tales made by Keith Donohue and Carol Taaffe (noting, with respect to Taaffe’s account, Aisling Ní Churraighín’s 
separate but connected discussion of O'Nolan and the practice of folklore collection) before turning to its comparative analysis of the tales in the context of the Sgéalta Mhuintir Luinigh, the Tyrone dialect of Irish they record, and their relationship to other elements in the column.

\section{O’Nolan and folklore collection}

The Sgéalta Mhuintir Luinigh context identified in Ó Conaire’s note is not mentioned in the remarks by the two other critics who have discussed these sketches, Donohue and Taaffe. Donohue provides a short, descriptive account of the tales as "usually short dramatic anecdotes [which] featured a number of different characters [..] from a fictitious Irish village and are mainly illustrative of the pervasive effects of English on Irish" (69). Donohue translates part of the tale published on 28 August 1941, in which the English words for "brothers", "money", "murders" and "country" are highlighted in italics, and proposes that the chronology of the publication of the tales links them to An Béal Bocht (69). Carol Taaffe’s account also links the tales to An Béal Bocht: the "Tales from Corkadorky [...] celebrated the true misery, stupidity and cupidity of the Gaels. [...] None of the inhabitants of Corca Dorcha were any more fortunate than An Béal Bocht's Bónapart Ó Cúnasa”. This essay develops Donohue’s and Taaffe's remarks on this association by showing how the tales are not originally intended to be connected to An Béal Bocht, but rather that O’Nolan deliberately associates them with his upcoming novel from the third tale onwards. Taaffe's discussion draws attention to the key role of Slánabhaile as an interlocutor who interrupts the narrative. Slánabhaile is a common Irish expression meaning "safe home” or "get home safely" and the character of Slánabhaile is the Irish-language precursor to the column's "Plain People of Ireland" (as noted in Donohue 90). Taaffe explains that Slánabhaile is a "pedant who corrected Myles’s expressions in pidgin Irish" (98) and who speaks in Irish represented by English phonetics. She gives an example from 5 July 1941 which begins with "a senseless, rambling story; an authentic piece of folklore from one of its elderly inhabitants. Many folktale ingredients are jumbled together - an ancient king's three sons, a journey to America, a bargain with the devil, and so on" (Taaffe 101). At this point Slánabhaile interrupts, and Taaffe translates his "impatient” interjection:

... neel bun naw bawr lesh an skayl. Nee higim kad taw ar school sa skayl i naykur ... kunahayv an gkirun tú skayl sa pawpeyr naw fwil ayn bree lesh awgus naw tigin tú fayn

... there's no top nor bottom to the story. I don't understand what's happening in it at all... why are you putting a story in the paper that has no sense in it and which you don't understand yourself. (Taaffe 102)

Myles responds that his "excuse is that he might get a folklore prize from the Oireachtas" and Taaffe's account also identifies that the key context for the tales is "the drive to collect folklore" and its "institutional sanction" in Ireland during the 1930s (Taaffe 101). She notes that the name of the Folklore Society of Ireland's journal, Béaloideas (meaning the oral tradition or folklore), is "mutated into 'Béal-IDIOCY' in Cruiskeen Lawn” (101), a section title which occurs in the first column identified by Ó Conaire as a part of the sequence.

Although she does not discuss the "Tales from Corkadorky”, Aisling Ní Churraighín provides a detailed account of O'Nolan's engagement with the history of folklore collection which is also relevant to this analysis. Ní Churraighín focuses her discussion on the episode of chapter three in An Béal Bocht in which a "fear uasal" ("noble gentleman") from Dublin arrives to record Irish spoken in Corca Dorcha using a "gramafón" and subsequently presents the recording of a pig grunting he captures to great acclaim at a conference of Celticists in Berlin 
(O’Brien, An Beál Bocht 35-7; Collected Novels 431-3). Ní Churraighín explores the ethical problems involved in the practice of collectors who, in pursuit of the riches of a pure Irish, seek out poverty, illness and illiteracy in their subjects. Ní Churraighín (25) notes that O’Nolan, as "Count O’Blather”, had taken aim at folklore collectors earlier in the short-lived comic magazine Blather, with an October 1934 article entitled "Ceist na Gaedhilge / Béal Idiots / Sean-Scéal ó Shean-Lad” ("The question of the Irish language / Oral idiots / An old story from an old lad"), "in which the collectors bind and bat an old man to force him to provide them with a parodic bogus folk tale” (O’Leary 117). As Ní Churraighín puts it: "Tógann Brian Ó Nualláin ról an eitneagrafaí air féin agus béim á leagan aige ar an teannas idir na bailitheoirí agus an scéalaí" ("Brian Ó Nualláin takes on the role of ethnographer, emphasizing the tension between collectors and the storyteller”, Ní Churraighín 29).

\section{Munterloney Folktales}

Published in the spring of 1933, Sgéalta Mhuintir Luinigh is an academic study representing years of patient effort by Professor Ó Tuathail, a member of the Gaelic League who became Professor of Modern Irish at Trinity College in 1929 and specialised in "Ulster eighteenthcentury poetry, dialects, placenames and folklore” (Ó Tuathail 103). Ó Tuathail visited the area of "the parishes of Upper and Lower Badoney - the territory running north to south along the western escarpment of the lofty spine of the Sperrin Mountains" in County Tyrone which is known as Muintir Luinigh or Munterloney, six times between 1929 and 1932, using an early dictaphone to record oral accounts on wax cylinders, consulting newspapers and manuscripts and "supplementing his own offerings with the fruits of other collectors' labours in the field" (Ó Tuathail 56, 104, 73-81). In this respect, he may partially inspire the "fear uasal" ("noble gentleman") in chapter three of An Béal Bocht who records the voice of a pig in Corkadorky using a "gramafón" and presents his findings in Berlin (O’Brien, An Beál Bocht, 35-7; Collected Novels, 431-3). To collect his material Ó Tuathail largely relied on conversations with Eoin Ó Cianáin, a local fluent in spoken Irish but who could only read and write in English. The book, now available in a dual-language edition, contains a description of the Tyrone dialect and the records of more than fifty folktales along with songs and proverbs, comprising "the first and only comprehensive collection in book form of Tyrone folklore in the Irish language” described by Gerard Murphy in a 1933 review for the Béaloideas journal as "a faithful record of the spoken Irish of Tyrone" and "a collection representative of what remains of Gaelic tradition in Munterloney" ("Foreword” by Séamas Ó Catháin in Ó Tuathail 44-60, citing Murphy 100-2).

The publication of the book was rushed to comply with a mandate to focus on publishing as much material in Irish as possible "laid down by Ernest Blythe” (Ó Tuathail 178), the Cumann na nGaedheal Minister of Finance between 1923-1932 who took an active interest in managing Irish cultural life. He founded An Gúm, the national Irish-language press, endowed the Abbey Theatre with a yearly subsidy of $£ 1,000$ and became its managing director from 1941-67 (Foster 500). Blythe had already cut the Irish Folklore Institute's original funding of $£ 500$ a year to $£ 300$ in dissatisfaction at its performance in this respect; however, when the book was rushed out in response, it "drew a tart response from the Institute's paymasters who wrote to convey their displeasure that, contrary to expectations, the book contained so much material in English”, presumably referring to its preface, phonology and footnotes (Ó Tuathail 178). This bungling controversy may have drawn O’Nolan's satirical eye to the collection. He would also have been interested in any collection of the Irish spoken in County Tyrone. His father had "perfected his own Irish in Cloch Cheannaola and on Tory Island” in neighbouring County Donegal, according to O’Nolan’s brother Ciarán (Ciarán Ó Nualláin 9). Brian and his siblings spent their early childhood in Strabane in County Tyrone, 
and Ciarán remembers "listening to the talk of the town" where people came in "from Castle Derg, from Gurteen, from the Sperrins and Dunmanway, Bridgetown and Castlefin. It must be remembered that the cursed border did not exist in those halcyon days" (Ciarán Ó Nualláin 323). Ó Conaire describes O’Nolan's background as a "family environment in which education, literature, the Irish language, culture, and learning held significant importance” and this family had roots in Tyrone (Ó Conaire, “Scholarly Background” 5). O’Nolan’s paternal grandfather, Daniel Nolan, taught music in Omagh before transferring to Belfast; his paternal grandmother Jane, “also known as Sinéad”, was “from Eskeredooey” in Tyrone and spoke Irish (Ó Conaire, "Scholarly Background" 5). An uncle who died at a young age, Padraig, was a member of the Gaelic League and "regularly participated at feiseanna, performing recitations” (Ó Conaire, "Scholarly Background” 5-6). His uncle Gearóid, a scholar of multiple languages including Irish, was, like his father Micheál, educated in Coill an Chlochair, Tyrone (Ó Conaire, "Scholarly Background" 6). His mother, Agnes, was also from a family local to Strabane (Ó Conaire, “Scholarly Background” 20). O’Nolan's family roots in County Tyrone help explain the interest that led him, as this essay argues, to pay attention to the record of some of the last surviving oral folktales spoken in Tyrone Irish, and to pay homage to it in "Cruiskeen Lawn".

\section{Comparative analysis}

After outlining some general similarities between the texts in terms of language and phonology, the section conducts a comparative reading of Sgéalta Mhuintir Luinigh and the content of the first tale to be published in "Cruiskeen Lawn" on 8 February 1941. In doing so, the section seeks to demonstrate beyond doubt that Sgéalta Mhuintir Luinigh, and the Tyrone dialect features it records, represent the primary contextual frame for O'Nolan's “Tales from Corkadorky”, which he subsequently associates with An Béal Bocht. It is immediately obvious that O'Nolan's tales adhere to a formulaic folktale opening which, although not limited to tales found in Sgéalta Mhuintir Luinigh, is a particularly common opening to the stories told by Eoin Ó Cianáin. In nearly every one of the collected stories the opening runs as follows:

Bhí fear insa tír seo i bhfad ó shoin, thíos air a’ [PLACE], a dtóirfí [NAME] air.

There was a man in this country long ago, down near [PLACE], by the name of [NAME]. ${ }^{2}$

Each of the "Tales from Corkadorky" is also signposted by its use of this formulaic statement. Table 2 shows the formula used of the first four of the tales as listed in Table 1. On the left the words printed in Gaelic script (cló Gaelach) have been reproduced here in italics and words appearing in Roman script (cló Rómhánach) in non-italics.

Table 2

Formulaic opening statements from first four tales as listed by Ó Conaire (Myles 263)

\begin{tabular}{|l|l|l|}
\hline Date & Excerpt & Translation \\
\hline 08/02/1941 & $\begin{array}{l}\text { Well, bhí fear ar a mbaile ar a dtug- } \\
\text { taoi Niall Dubh agus by Dad duine } \\
\text { mór éascamh láidir abhí ann. }\end{array}$ & $\begin{array}{l}\text { Well, there was a man from the } \\
\text { town named Niall Dubh and by Dad } \\
\text { here was a big swift strong man }\end{array}$ \\
\hline $15 / 02 / 1941$ & $\begin{array}{l}\text { Bhí fear ionn ar a' bhaile se' darb } \\
\text { ainm Téig agus d'írigh se lá 'mhain } \\
\text { agus fuaidh air shiúl [...] }\end{array}$ & $\begin{array}{l}\text { There was a man here of the town } \\
\text { named Téig and he got up one day } \\
\text { and went walking... }\end{array}$ \\
\hline
\end{tabular}




\begin{tabular}{|l|l|l|}
\hline 18/02/1941 & $\begin{array}{l}\text { Bhí fear insa tír-se fad oshoin a a } \\
\text { dtóirfí Téig air agus bhí se ina chónuí } \\
\text { leis hín i dteagh bheag. }\end{array}$ & $\begin{array}{l}\text { There was a man in this country } \\
\text { long ago named Téig and he was } \\
\text { living on his own in a small house. }\end{array}$ \\
\hline 01/03/1941 & $\begin{array}{l}\text { Bhí fear 'na chónuí thuas innseo aig } \\
\text { a'Baile Bocht a dtóirfi [Éamon an } \\
\text { Chnoic] air [...] }\end{array}$ & $\begin{array}{l}\text { There was a man living up here in } \\
\text { the Baile Bocht called [Eamon a' } \\
\text { Chnoic] }\end{array}$ \\
\hline
\end{tabular}

Source: “Cruiskeen Lawn” in Irish Times archive, cited by date.

a The correct expression is "ó shoin” but this version may be an intentional as a part of O’Nolan's rendering of contractions in the Tyrone dialect.

b Printed "Eamon a' Chruic", which is probably a misprint of "Éamon an Chnoic" ("Ned of the Hill”), the title of a traditional Irish song.

This similarity alone would not be enough to demonstrate that O'Nolan's tales are a direct response to the Munterloney tales (it would have been possible for him to borrow such a formula from elsewhere and then choose to repeat it, for example). To make the case firmer, Table 4 below takes a number of the "particular" Tyrone dialect features identified by Ó Tuathail (368) and identifies their corresponding examples in the "Tales from Corkadorky":

\section{Table 4}

Tyrone dialect forms identified by Ó Tuathail reproduced in the "Tales from Corkadorky":

\begin{tabular}{|c|c|}
\hline Tyrone dialect example & Example occurrences in “Tales from Corkadorky” \\
\hline \multicolumn{2}{|c|}{ 2. Vowel-lengthening: “é > í” (380) } \\
\hline "Séamus > Síomus" & $\begin{array}{l}\text { "Síomus" appears in tales published on 8/4/41, 5/7/41, } \\
30 / 08 / 41,3 / 10 / 41 \text { and } 22 / 1 / 42\end{array}$ \\
\hline féin > hín & $\begin{array}{l}\text { “Má tá hín” (15/2/41); “bhí se ina chónuí leis hín } \\
\text { (18/2/41); "Ní fheicim hín e” (22/3/41) }\end{array}$ \\
\hline éirigh > írigh & “d’írigheadh se” (18/2/41); “d’írí se lá ‘mháin” (5/7/41) \\
\hline \multicolumn{2}{|l|}{ 28. Loss of consonant (525) } \\
\hline Mac > 'ac & Mac > 'ac occurs in tales on 22/3/41, 5/7/41 and 28/8/41 \\
\hline \multicolumn{2}{|l|}{ 27. $d>t(505)$} \\
\hline "dul > tul” & institiúid > institúit occurs in tale published on 8/2/41 \\
\hline \multicolumn{2}{|c|}{ 29-30. Interchange of c and $g(530-2)$} \\
\hline “gach” ('each’, ‘every') > cach & “Cach a’n lá” (7/5/41) \\
\hline tháinig $>$ tháinic & “Theinic se” $(18 / 2 / 41)^{\mathrm{a}}$ \\
\hline
\end{tabular}

Sources: Sgéalta Mhuintir Luinigh, numbered as per Ó Tuathail’s categories of phonological characteristics, cited by location; “Cruiskeen Lawn” in Irish Times archive, cited by date.

a “Theinic” is likely a misprint of “tháinic”, Tyrone dialect for “tháinig” (“came’)

As well as using these phonological features of the Tyrone dialect as described by Ó Tuathail, O'Nolan's tales also mimic the frequent use of specific expressions or words used throughout Sgéalta Mhuintir Luinigh which are, in turn, repeated in almost every one of his own tales, such as “ó shoin” ("long ago") and “ionn”, a vowel-lengthened version of "ann” ("there”). The case for influence is made even stronger by a thematic analysis of the first tale, published on 8 February 1941, in which the "Tales from Corkadorky" format first evolves of a section titled "Béal-IDIOCY". An analysis of this opening reveals how the idea for what will become named 
as the "Tales from Corkadorky” undoubtedly emerges from Myles engaging with the Folklore Institute and the stories he finds in one of its publications, Sgéalta Mhuintir Luinigh.

The column begins with Myles announcing that "My attention has been drawn to remarks made by Senator Desmond Fitzgerald" in a debate on the "Institute on Advanced Studies Bill, 1939”. Fitzgerald recounts a conversation with "a supreme master of philology generally and a supreme master of ancient Irish" who is nevertheless unable to conduct a conversation in modern Irish. Myles takes advantage of the judiciously anonymous subject of Fitzgerald's anecdote to claim that, "I repudiate this charge categorically. I never dined with Senator Fitzgerald in my life”. We are then introduced to Myles’s satirical commentary on the practice of collecting folklore (as before, Roman script is represented by non-italics):

Bhfuil sé [macántacht] ${ }^{3}$ a rádh gur ghlac mé síos an píosa béaloideasa so ó seanóir i gConamara! Stop mé má chuala tú roimhe é.

"Well, bhí fear ar a' mbaile seo ar a dtugtaoi - "

Ach fán! ${ }^{4}$ Cuimhnigh go bhfuil Institúit ${ }^{5}$ Béaloideasa againn! Ná síl gur scéal beag grinn do leanbhaí an scéal so. Piosa seanchais atá ann a tháinic ${ }^{6}$ aniar chugainn ó glún go gl'un treasna aigéan an ama. Léirigheann sé dúinn go grinn dul an daemon gaedhealaigh, mínigheann sé dearcadh ár sinnsira ar an saogal - a n'uaisleacht, a néigeas, a n-eirim, a meanma scéalaidheachta, a gcreideamh i nDia, a mbinneas cainnte, a n-umhluigheacht, a mbochtanas, a ndúil sa digh, a gciocracht, a-

Acht ni mise Deasmumhan Mac Carthaigh, slán mar a h-innstear é. Let out the $\operatorname{dog} !$ Ar [aghaidh] ${ }^{7}$ leis an scéal!

Tis honest to say that I took down this piece of folklore from an elder in Connemara. Stop me if you heard it before.

"Well, there was a man in this area named -"

But wait! Remember we have a Folklore Institute! Do not think that this is a small, funny tale for children. It is a piece of lore that came to us from generation to generation, across the oceans of time. It shows to us the nature of the Gaelic daemon, it explains our ancestors' view on life - their nobility, their wisdom, their intelligence, their soulful storytelling, their belief in God, the sweetness of their speech, their humility, their poverty, their fondness for drink, their gluttony, their story!

But I am not Desmond McCarthy, be sure of it. Let out the dog! On with the

(It should be noted that this parodic version of Gaelachas strays into quite polyphonic territory when the final epithets, which could mean in one sense "the desire in their hearts, their consciences" veer into meaning "their fondness for drink, their gluttony".) Following this introduction, Myles relays the ersatz folktale itself under two more subtitles that are dropped in later instances of the tales as he consolidates the format of the series. The subject matter of the tale is inspired by a repeated theme of Irish folklore: a man who attempts to outwit the devil. There are numerous examples of tales like this in Sgéalta Mhuintir Luinigh. The first tale, titled as "Jack", is about the adventures of a man after he prevents the devil from stealing the skin of his dead father, who, in a comic turn akin to Myles's own humour, was fond of saying "Go mbuinidh an diabhal a' croiceann duíom, ${ }^{8}$ má bhím ag ársú bréag” ("May the devil skin me if I'm lying”; Ó Tuathail 1254, 1179). Bargains with the devil recur in the collection: one tale begins "Bhí fear insa tír seo i bhfad ó shoin agus dhíol se e hín ${ }^{9}$ leis a’ diabhal” ("There was a man in this area long ago who sold himself to the Devil"; Ó Tuathail 2564, 2515). The collection also contains two versions of the "Liam an tSoluis" ("Will o' the Wisp") tale, about a canny blacksmith who continually frustrates the devil and makes his fortune as a result, only 
to be denied entry to both heaven and hell when he dies (since the devil is tired of his tricks) and is condemned to wander the earth as ignis fatuus misleading mortals instead. Versions of the "Will o' the Wisp" tale form part of the sources for Father Peadar Ua Laoghaire's modern Irish novel, Séadna (1894-1904), where a cobbler repeatedly outwits the devil, and, as one of the universal themes for folklore that Myles refers to in the 23 October 1944 column, the "Will o' the Whisp” is incorporated in Goethe's Faust.

In the first tale, Myles's parodic version of this story knits together plot elements and vocabulary from various tales found in Sgéalta Mhuintir Luinigh to depict a man named "Niall Dubh" (Black Niall) who meets a devil on the road holding a bag which he says is full of pennies. Niall can't hear the pennies clattering together, and so eventually the devil invites him to take a closer look. Before he knows it, Niall is swept into the bag and taken into hell and "níor cluineadh scéal' ar bith air ó shion” ("there was never a story about him heard again"). The synopses and notes provided in Table 1 show how this theme of a comic confrontation with the devil recurs five times in O'Nolan's series. The close attention to this theme in the column forms an important part of the background to O'Nolan's choice of a deal with the devil for the plot of Faustus Kelly (1942-3) and the specific joke in this tale will be repeated at the conclusion of the play, when the devil is so exasperated by Kelly's overblown and clichéd rhetoric that he refuses to take him to hell (O’Brien, Plays and Teleplays 116).

The influence of Sgéalta Mhuintir Luinigh is also clear in the way that the dialogue of this tale models, in an exaggerated form, the dialogues with the devil in stories in Sgéalta Mhuintir Luinigh. In "Cruiskeen Lawn", we are treated to the following comic sequence:

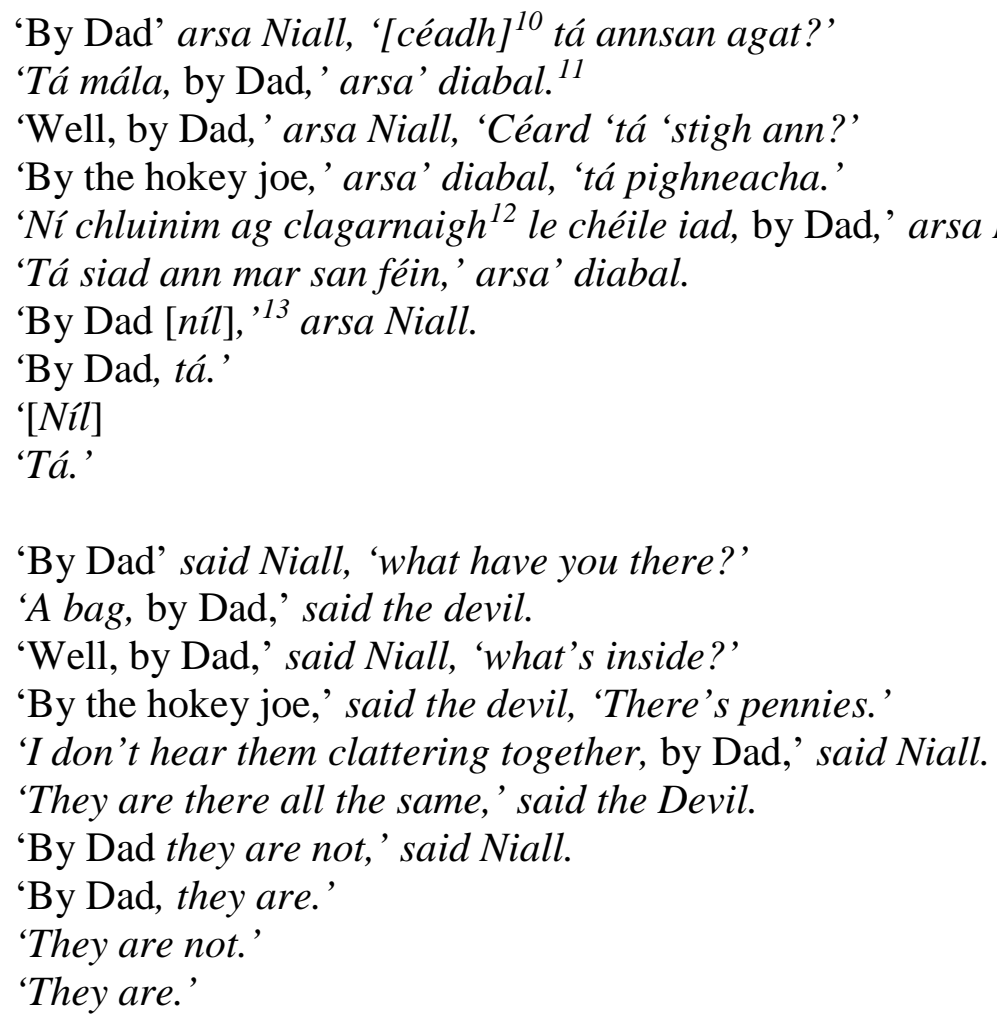

This comic tussle between Niall and the devil seems to be inspired by the wording of a similarly comic sequence in Sgéalta Mhuintir Luinigh, in which Jack wrestles with the devil for the skin of his dead father, who was fond of saying "May the Devil skin me if I'm lying":

'Cha charr’ann tú sin,’ arsa Jack, arsa seisean.

'Carrachaidh,' adeir an diabhal. 
'Cha charr’ann,’ arsa Jack.’

('You won't move that,' said Jack, said he.

'I will!' said the Devil.

'No, you won't!' said Jack')

(Ó Tuathail 1185, 1263, 1192)

The column plays with alternating Gaelic and Roman script to model the hybrid nature of spoken Irish and Irish identity and, as if to cover to his tracks, in the third tale, the first to be titled “Tales from Corkadorky”, O’Nolan switches the main typeface from Gaelic to Roman.

\section{Unstable stories}

It is evident from the foregoing analysis that the tales do not emerge fully formed but rather bubble forth from an initial framing within adjacent material. The first example of something recognizable as a tale on 8 February 1941 appears as part of a tripartite structure of subtitles: the opening gambit or frame narrative; the start of the tale in a section entitled "SEADH. AN SCÉAL" ("Ah yes, the story"); and its conclusion in a section entitled "DEIREADH AN SCÉIL" ("End of the story"). In this example, as in those of 15 February 1941 and 22 January 1942, the column concludes with another section that could be also categorised as an independent series, the unreliable historical quotations of "AG FÉACHAINT SIAR" ("Looking Back"). These sections are often bowdlerised excerpts from texts and speeches of the pre-Independence language revival era, thus working to cast an ironised veneer of authenticity over the ersatz folklore preceding them. In the second example the tale component is now titled "SEODA ÁR SEAN" ('Treasures of Old') which confers on it the same feeling of an archival retrieval as "AG FÉACHAINT SIAR". In this column there is also the appearance of a distinct series of its own, written in English but titled "SEÁN CÉITINN" (literally, John Keating). This is the original Gaelicised title of the long anecdotes that would become known as the "Keats and Chapman" sketches in anthologised collections (O'Brien, Best of Myles 180-200; Keats and Chapman), beginning life as English language material amidst the largely Irish column that appears first a few weeks earlier on 2 January 1941. It is introduced by a paragraph in Irish printed in Gaelic script stating that this a funny story given to Myles by a friend which John Keats told about Alexander the Great, effecting a contrived and well-demarcated transition between sections in a column that elsewhere intermixes English and Irish, Gaelic and Roman script. Keats and Chapman episodes go on appear twice more in the eleven columns that contain a tale.

As such, the "Tales from Corkadorky" can only be fully understood as a series in its developing interaction with other subgenres developed in the column, whether that is sketches which go on to become classics, like Keats and Chapman, the Plain People of Ireland or the WAAMA sequence, or less successful experiments. On 22 March 1941 there is a section before the Keats and Chapman episode entitled "CORKADORKY NATIONAL SCHOOL" which is a sketch in which a "Colleen Ogue" ("young girl” in Myles's phonetically English Irish) is instructed by the character Téig to go to school in which she complains that only English is spoken there and protests “Goidé'n mhaith Béarla i nEirinn?” ("What's the use of English in Ireland?"). This is the germ of a potential series that does not appear again in the column and seems closely related to the schooling episode in An Béal Bocht (24-6, Collected Novels 424-5) which, in turn, is modelled on the "Jamie Gallagher" chapter of Séamus Ó Grianna’s Caisleán Óir (Ó Grianna 8). On 3 October 1941 there is a section after the tale entitled "SMAOINEAMH" ('A thought'), printed in Gaelic script, in which Myles proposes to establish an Irish-speaking version of Seán Ó Faoláin’s organisation for writers. WAAMA has 
been mentioned only once before in passing during the previous week, on 26 September 1941, and so this final thought after the tale seems to provide the inspiration for Myles to fictionalise the association as part of the series that has become one of the column's most famous inventions: the book-handling and escort services sequence (O’Brien, Best of Myles 15-40). The link between Corkadorky and WAAMA may be a sharp difference in opinion between Ó Faoláin and O’Nolan about Muiris Ó Súileabháin’s Fiche Blian ag Fás (Twenty Years $a$-Growing). Ó Faoláin praised the book as "the root of the new sprout" in Irish-language fiction whereas, as Richard Murphy argues, O’Nolan's “apparent neglect” of the novel as an influence on An Béal Bocht testifies to his view that Ó Súileabháin's efforts had rendered the Irish-language autobiography "beyond repair” (Murphy 137). Finally, as discussed earlier, the tales are subject to increasingly frequent interruptions from Slánabhaile, a strategy of depicting the putative audience for itself that becomes one of the central dialogic features of "Cruiskeen Lawn” and its Plain People of Ireland.

\section{Conclusion}

This essay has demonstrated, with linguistic and phonological comparisons and through a closer analysis of the first tale, that the "Tales from Corkadorky" constitute a parodic response (and a homage) to the Tyrone folktales collected in Sgéalta Mhuintir Luinigh which is subsequently associated with the Corcha Dorcha of An Béal Bocht. However, the essay has also shown, by analysing the evolving structure of this set of columns and their jostling subsections, that the "Tales from Corkadorky" are as unstable as a standalone "series" as any other repeated trope in "Cruiskeen Lawn": in contrast to the impression given by their arrangement into distinctive sections in the Best of Myles collection, the column's sketches can only be properly understood as part of a complex fabric of interwoven themes and ideas. In this respect, the influence of the oral tradition on O’Nolan helps to explain the structure of his modernist satire. Flore Coulouma has suggested that the collaborative practices of the bardic oral storytellers are relevant to our understanding the use of formulaic tropes in O’Nolan's novels (Colouma 30-3), and in an essay about O'Nolan's mediation of the Irish oral tradition, Vito Carrassi draws on the ideas of Lauri Honko and Richard Bauman, which deal with "the interaction between a traditional corpus coming from the past and the individual innovation of one or more performers of the present”, to suggest that O'Nolan's texts participate in a process which endeavours to reverse the way that folklorists, in their earnest efforts to record the oral tradition, transform an initially "open" event into an "unalterable, closed system" (original emphasis). Carrassi argues that "[through] his works it appears quite clear how literature, resuming and reshaping the folk narrative tradition, may contribute to keep it alive and meaningful" (34, 35, 40). In this respect, the "Tales from Corkadorky" are indeed, as stated in the tale published on 15 February 1941, an example of "Myles na gCoplaeen, an shanachie oosal Gayluck, hard at it" in a modernist re-performance of the Gaelic oral culture. The Tyrone Irish material is lifted out of its fixed, stable form, as preserved in Sgéalta Mhuintir Luinigh, and joyfully re-integrated into the open-ended textual situation of the daily newspaper.

\section{Notes}

\footnotetext{
${ }^{1}$ Unless mentioned, translations are my own. The author wishes to acknowledge the kind assistance of Dr. Eoin Byrne, NUI Galway, who reviewed and improved the translations from the “Tales from Corkadorky” in this essay, suggested additional Irish-language secondary sources and helped to clarify the overall argument.
} 
${ }^{2}$ For example, this opening or a close variation on it appears in "Jack” (1247), "An Fear a Bhuail Bab air an Bhás” (1825), “An Gabhar Beag Cóir Corcra” (1917), “An Deór a Bhí gConuí sa Chúil-Teach” (2017), "Buchaill na Cruite" (2064), "An Tarbh Donn” (2135), and so on. The same formulaic opening is also found in two of the Donegal folktales collected by Seán Ó hEochaidh (see Main Manuscript Collection, National Folklore Collection, UCD, Web. 8 Feb. 2021, <https://www.duchas.ie/en/cbe/9000137/7067404/9064749> and $<$ https://www.duchas.ie/en/cbe/9000716/7132368/9064436>).

${ }^{3}$ Printed as "machtanach" which seems likely to be a misprint of macántacht ("honesty") ("macántacht", Teanglann, Web. 9 Feb. 2021 <https://www.teanglann.ie/ga/fgb/mac\%c3\%a1ntacht>.

4 "Fán” should correctly read "fan” ("wait”). However, even though Ó Tuathail does not list a specific a > á transformation, I suspect that O’Nolan is imitating the Tyrone vowel-lengthening of which Ó Tuathail provides many other examples, in readiness for introducing the Munterloney-inspired material later.

${ }^{5}$ IE, "institiúid” Teanglann, Web. 9 Feb. 2021 < https://www.teanglann.ie/ga/fgb/institi\%c3\%baid>, an example of the "d > t" phonological shift which Ó Tuathail identifies (505).

6 “tháinic" (from "tháinig”) is one of the Tyrone-dialect g > c substitutions Ó Tuathail identifies (532).

${ }^{7}$ Printed as "agaidh" which is likely a typesetting error.

${ }^{8}$ Prepositional pronoun "díom" ("from me", "off me") modified according to "palatal d > non-palatal d" substitution (Ó Tuathail 494).

9 "hín” (from “féin”) is an example of Tyrone-dialect “é > í” substitution (Ó Tuathail 380).

${ }^{10}$ Printed as "céardh" which is likely a typesetting error.

${ }^{11}$ The column prints an apostrophe between "arsa" and "diabhal”, perhaps to indicate a definite article.

12 "clagarnaigh" is "clagarnach”, Teanglann.ie, Web. 9 Feb. $2021<$ https://www.teanglann.ie/ga/fgb/clagarnach> modified as per the adh, agh shift that Ó Tuathail notes applies equally in Glenties and Tyrone dialects (411).

${ }^{13}$ Printed as "ni' $l$ " which is likely a typesetting error, mistaking the fada for an apostrophe.

\section{Works cited}

Coulouma, Flore. Diglossia and the Linguistic Turn: Flann O'Brien's Philosophy of Language. Dublin: Dalkey Archive Press, 2015.

Carrassi, Vito. "Between Folk and Lore: Performing, Textualising and (mis)Interpreting the Irish Oral Tradition”. Estudios Irlandeses 12.2 (2017): 32-46.

Donohue, Keith. The Irish Anatomist: A Study of Flann O’Brien. Dublin: Maunsel \& Company, 2002.

De Paor, Louis. "Satire and Subversion in An Béal Bocht”. Ireland and Australia, 1798-1998: Studies in Culture, Identity and Migration. Ed. Philip Bull, Frances Devlin-Glass and Helen Doyle. Sydney: Crossing Press, 2000: 232-9.

Foster, Roy. Modern Ireland: 1600-1972. London: Penguin 1989.

Murphy, Gerard. Review of Sgéalta Mhuintir Luinigh. Béaloideas 4.1 (1933): 100-2

Murphy, Richard. “'A root of the new sprout?’: Flann O’Brien, Minor Literature and the Modern Gaelic Canon”. “Is it about a bicycle?”: Flann O'Brien in the Twenty-First Century. Ed. Jennika Baines. Dublin: Four Courts Press, 2011: 67-82.

Na gCopaleen, Myles / Flann O’Brien / Brian O’Nolan. . “Ceist na Gaedhilge / Béal Idiots / Sean-Scéal ó Shean-Lad”. Blather 1.2 (October 1934): 32-3.

. “Cruiskeen Lawn”. Irish Times, 8 February 1941: 8; 15 February 1941: 8; 18 February 1941: 6; 1 March 1941: 8; 22 March 1941: 8; 8 April 1941: 4; 5 July 1941: 6; 28 August 1941: 6; 30 August 1941: 3; 3 October 1941: 3; 22 January 1942: 2; 29 May 1942: 3.

- An Béal Bocht nó An Milleánach: Drochscéal ar an drochshaol curtha in eagar le Myles na gCopaleen. Cork: Mercier, 1986 (1941).

Best of Myles. London: Picador, 1977 (1968).

The Various Lives of Keats and Chapman, including "The Brother". London: Souvenir, 2010 (1976). 
The Complete Novels: At Swim-Two-Birds, The Third Policeman, The Poor Mouth, The Hard Life, The Dalkey Archive. introd. Keith Donohue. London: Everyman, 2007. . Plays and Teleplays. Ed. Daniel Keith Jernigan. Champaign, IL: Dalkey Archive Press, 2013.

. Collected Letters of Flann O’Brien. Ed. Maebh Long. Champaign, IL: Dalkey Archive Press, 2018.

Ní Churraighín, Aisling. "Béal Bocht an bhéaloidis: Myles na gCopaleen agus a luath-chritíc ar an bhailiú ghairmiúil”. Comhar Taighde 3 (Deireadh Fómhair 2017).

http://comhartaighde.ie/eagrain/3/nichurraighin/; references are to paragraph number.

Ó Conaire, Breandán. Myles na Gaeilge: Lámhleabhar ar shaothar Gaeigle Bhrian Ó Nualláin. An Clóchomhar Tta: Baile Átha Cliath, 1986.

"Review: Flann O'Brien, Myles na gCopaleen and Irish cultural debate". Studia Hibernica 35 (2008-2009): 195-207.

. "Brian Ó Nualláin/O’Nolan: Scholarly Background and Foreground”. The Parish Review: Journal of Flann O'Brien Studies 4.1 (Spring 2018): 4-16.

Ó Grianna, Séamus. Caisleán Óir. Baile Átha Cliath, 1976 (1924).

O'Leary, Philip. Gaelic Prose in the Irish Free State, 1922-1939. University Park, PA: Pennsylvania State University Press, 2004.

Ó Nualláin, Ciarán. The Early Years of Brian O'Nolan/Flann O'Brien/Myles na gCopaleen. Trans. Roisín Ní Nualláin. Ed. Niall O’Nolan. Dublin, Lilliput: 1999. First publ. as Óige an Déarthár .i. Myles na gCopaleen. Baile atha Cliath: Foilseacháin Náisiúnta Teo, 1973.

Ó Tuathail, Éamonn. Sgéalta Mhuintir Luinigh (Munterloney Folktales). Dublin, University College Dublin - The National Folklore Collection, 2015 (1933). Kindle edition; references are to 'location', not page.

Taaffe, Carol. Ireland Through the Looking-Glass: Flann O'Brien, Myles na gCopaleen and Irish Cultural Debate. Cork: Cork University Press, 2008.

Received: 1 November 2020

Revised version accepted: 11 February 2021

Tobias Harris recently completed his $\mathrm{PhD}$ on Brian O'Nolan and the European avant-garde at Birkbeck College, University of London. He is the winner of the "Best essay-length study on a Brian O’Nolan theme (2015-16)” prize for “The Catastrophe of Cliché: Karl Kraus, Cruiskeen Lawn, and the Culture Industry,” published The Parish Review, has published an essay, "Blather, Razzle and Dada” in Modernist Cultures and a chapter on O’Nolan, Joyce and Irish cultural production in the recent Flann O'Brien: Gallows Humour collection.

toby.harris87@gmail.com 